\title{
PRZEPŁYW TOWARÓW PRZEZ POLSKO-ROSYJSKA GRANICĘ. POLSKO-ROSYJSKI HANDEL ZAGRANICZNY W MOMENCIE INTEGROWANIA SIĘ POLSKI Z UE. WYBRANE ASPEKTY EKONOMICZNE
}

\section{Wprowadzenie}

Problemy związane z funkcjonowaniem granic państwowych nie traca, lecz zyskują na znaczeniu w dobie transformacji, integracji i globalizacji. Jednakże mają one wciąż wymiar polityczny, ekonomiczny i społeczny i tym samym powinny być rozpatrywane w różnych aspektach, w tym zwłaszcza w układzie prawno-ekonomicznym. Muszą też być rozpatrywane z punktu widzenia teorii stosunków międzynarodowych i stąd wynikającej polityki zagranicznej. ${ }^{1}$ Należy także je rozpatrywać z punktu widzenia międzynarodowych stosunków gospodarczych i z tym związanej zagranicznej polityki ekonomicznej. Przemiany geopolityczne dokonujące się w Polsce i jej sąsiedztwie na przełomie XX i XXI wieku utworzyły nową rzeczywistość polityczną i gospodarczą wzdłuż polskich granic. Powstały nowe suwerenne państwa. Gospodarki tych państw realizują w różnym tempie i w różny sposób przemiany ustrojowe i gospodarcze, tj. transformacje. $Z$ jednej strony mamy do czynienia z transformacją radykalną (Polska, Czechy, Słowacja, Niemcy Wschodnie). $\mathrm{Z}$ drugiej zaś dostrzegamy co najwyżej przypadki transformacji mniej radykalnych - gradualnej na Białorusi i mieszanej, polegającej na stopniowym przechodzeniu od

$1 \quad$ W związku z tym dość bogata jest literatura podnosząca te kwestie. Ze zrozumiałych względów najczęściej jednak odnosi się do poszczególnych tylko aspektów tej interdyscyplinarności. Trudno jest więc wskazać opracowania naukowe zwarte (monografie), które w sposób kompleksowy to prezentowałyby. Można natomiast znaleźć takie, które podnoszą przynajmniej kilka elementów (aspektów) tej interdyscyplinarności. Między innymi, szczegółowo zagadnienia dotyczące prawno-ekonomicznych aspektów kształtowania się w tym okresie swobody przepływu towarów i ludzi prezentują Aleksander Maksimczuk i Leszek Sidorowicz w czterech monografiach: 1. Ochrona granic i obsługa ruchu granicznego, Warszawa 2007; 2. Graniczny ruch osobowy i towarowy w Unii Europejskiej, Warszawa 2007; 3. Graniczna obsługa ruchu osobowego i towarowego w Unii Europejskie (wybrane aspekty), Warszawa 2008; 4. Polska granica wschodnia w warunkach transformacji (wybrane aspekty), Białystok 2008. W nieco innym i trochę węższym ujęciu znajduje to także odzwierciedlenie, (w:) Adamowicz M., Siedlecka A., (red.), Ruch graniczny w kontekście poszerzania Unii Europejskiej, Biała Podlaska 2008, oraz w monografii wydanej w języku rosyjskim: A. Maksimczuk, Pogranicznyj wywoz towarow w Ewrosojuzie, Mińsk 2009; a także w niektórych innych, które w tym opracowaniu w miarę potrzeb będą dalej wykorzystywane. 
Przepływ towarów przez polsko-rosyjską granicę...

gradualnej do radykalnej, jak to ma miejsce w Rosji i na Ukrainie. Taki stan rzeczy, panujący w sąsiedztwie Polski, musi być przyczyną powstawania wielu nowych problemów na odcinku współpracy gospodarczej i politycznej z tymi krajami

Przedmiotem rozważań prezentowanych w tym opracowaniu jest więc pewien fragment tego ww. szerszego zagadnienia, a konkretnie dotyczący współpracy Polski i Rosji w zakresie przepływu towarów przez polsko-rosyjską granicę w momencie integrowania się Polski z UE. Inaczej mówiąc, chodzi tu o najważniejsze aspekty ekonomiczne funkcjonowania polsko-rosyjskiego handlu zagranicznego w tym, jakby nie było, dla obu stron przełomowym momencie. Można też twierdzić, że w rzeczywistości sprawa sprowadza się także do ekonomicznych aspektów (warunków) realizacji jednej z czterech podstawowych swobód gospodarczych współczesnego świata, tj. swobody przeplywu towarów w kontaktach handlowych Polski i Rosji w momencie poszerzania się UE ("starej piętnastki") o nowych 10 państw na wschód. Tym samym odnosiło się to także do kwestii przenikalności granic ("nowej jakości" polsko-rosyjskich granic") w zakresie ruchu towarowego w związku z myślą przewodnią: „Przyjazna granica - niezbędnym elementem wzmacniania stosunków społeczeństw Polski i Federacji Rosyjskiej”, wynikajaca przecież już z samego tytułu monografi, której częściq składowa jest także to opracowanie.

\section{Polski handel zagraniczny w warunkach akcesji ze Wspól- notą Europejską - wstępna weryfikacja tzw. tła szerszego tutaj podnoszonego głównego problemu}

Już na samym początku podkreślenia wymaga fakt, że sam tylko 2004 rok, objęty horyzontem niniejszej wstępnej oceny w związku z jak wyżej sformułowanym tytułem tego opracowania, to zaledwie tylko kilkumiesięczny okres po zintegrowaniu się Polski z UE. Tym samym nie może on być jeszcze podstawą oceny wpływu tego wydarzenia na polskie obroty handlowe. Mimo to wydaje się zasadne dokonanie już pewnego, z pewnością jeszcze dość „ostrożnego” i z konieczności uproszczonego, porównania wyników handlowych osiagniętych w ostatnich miesiącach po akcesji z okresem pierwszych 4 miesięcy 2004 r. W ocenie z konieczności więc brano pod uwagę nie tyle dynamikę wzrostu obrotów w porównywanych okresach z uwagi na zniekształcający wpływ bazy odniesienia, lecz przede wszystkim bezwzględny poziom obrotów w poszczególnych miesiącach. 
Tabela 1. Obroty handlu zagranicznego Polski w 2004 roku w podziale na dwa podokresy: przed i po akcesji (w mln dol.)

\begin{tabular}{|c|c|c|c|c|c|c|}
\hline \multirow{2}{*}{ Grupa krajów } & \multicolumn{3}{|c|}{ I-IV.2004 r. } & \multicolumn{3}{c|}{ V-XII.2004 r. } \\
\cline { 2 - 7 } & eksport & import & saldo & eksport & import & saldo \\
\hline Polska & 22911 & 28426 & -5515 & 50870 & 59730 & -8860 \\
\hline UE-25, w tym: & 18738 & 19760 & -1022 & 39629 & 40350 & -722 \\
\hline Niemcy & 7273 & 6837 & 436 & 14821 & 14644 & 217 \\
\hline WNP, $w$ tym: & 1385 & 2566 & -1181 & 4404 & 6239 & -1834 \\
\hline Rosja & 613 & 1893 & -1280 & 2230 & 4498 & -2268 \\
\hline Kraje rozwijające się & 1209 & 3997 & -2788 & 3055 & 8519 & -5464 \\
\hline
\end{tabular}

Źródło: Ocena sytuacji w handlu zagranicznym Polski w 2004 roku, Ministerstwo Gospodarki, Warszawa 2005, s. 15.

Porównanie obrotów średniomiesięcznych w okresie przed i po akcesji w ich wymiarze bezwzględnym wskazuje na ich wzrost w okresie poakcesyjnym. Jest to widoczne w ujęciu ogólnym, jak też w zestawieniu z rynkami Wspólnoty Europejskiej w jej powiększonym już kształcie. Średni miesięczny poziom eksportu po akcesji $(6,4$ mld dol.) był o $11 \%$ wyższy niż przed akcesją, zaś po stronie importu o $5 \%$ wyższy $\left(7,5\right.$ mld dol. średnio w miesiącu). ${ }^{2}$

W okresie styczeń-kwiecień 2004 r. import z krajów spoza UE rósł wolniej niż przywóz z dotychczasowych państw członkowskich Unii i krajów przystępujących. W tym czasie na wzrost importu z tej grupy krajów największy wpływ miało przede wszystkim zwiększenie dostaw wyrobów klasyfikowanych jako maszyny i urządzenia (a więc drugiej, oprócz produktów mineralnych, grupy pod względem wartości przywozu z krajów trzecich). Ich import zwiększył się wówczas prawie o $50 \%$ w porównaniu z pierwszymi czterema miesiącami $2003 \mathrm{r}$. Znacznie wyższą niż w 2003 r. dynamiką charakteryzował się również import produktów chemicznych, wyrobów metalurgicznych oraz artykułów rolnych. Największe znaczenie dla wzrostu importu w tym okresie miało wyraźne zwiększenie dostaw z Chin. Dynamika importu z krajów trzecich, podobnie jak importu z krajów Unii Europejskiej,

2 W opracowaniu tym w zasadzie nie analizowano regulacji prawnych i instrumentów polityki handlowej Polski i Federacji Rosyjskiej, co wcale nie musi oznaczać pomniejszania ich roli. Są one dokładnie naświetlone w literaturze wymienianej w poprzednim odsyłaczu (tj. w przypisie nr 1.), do której w miarę potrzeb, we właściwych do tego miejscach, odwoływano się. Znajdują one przecież także swoje odzwierciedlenie w innych opracowaniach tej monografii. Zmiany w polsko-rosyjskiej wymianie handlowej analizowano na podstawie oficjalnej statystyki handlu zagranicznego, czasami posiłkując się informacjami Wydziału Ekonomiczno-Handlowego Ambasady RP w Moskwie, a także Ministerstwa Gospodarki. Tu konkretnie na podstawie: Ocena sytuacji w handlu zagranicznym Polski w 2004 roku, Ministerstwo Gospodarki, Warszawa 2005, s.10 i dalsze. 
okazała się jednakże w okresie maj - grudzień 2004 r. niższa niż w czterech pierwszych miesiącach $2004 \mathrm{r}$.

Wykres 1. Struktura geograficzna polskiego eksportu w 2004 r.
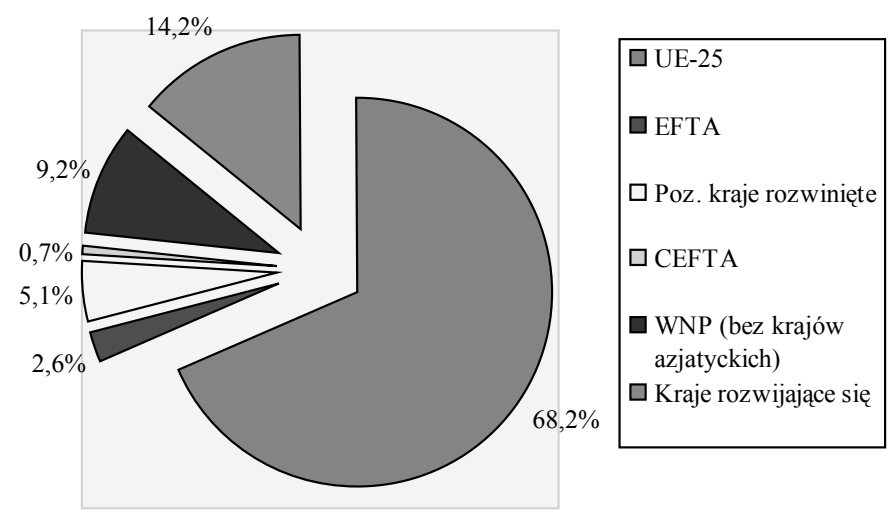

Źródlo: Ocena sytuacji w handlu zagranicznym Polski w 2004 roku, Ministerstwo Gospodarki, Warszawa 2005, s. 10.

Jednak w przypadku grupy tzw. krajów trzecich spowolnienie przywozu (importu) okazało się najmniejsze. Wynikało to jednak głównie ze wzrostu cen surowców energetycznych, przede wszystkim ropy naftowej (najwyższy przyrost importu odnotowano w tym okresie w grupie obejmującej paliwa mineralne). Natomiast w pozostałych najważniejszych (pod względem ich udziału w całości) grupach towarów, oprócz środków transportu oraz materiałów i wyrobów włókienniczych, dynamika importu w okresie maj - grudzień 2004 r. była znacznie niższa niż w okresie styczeń-kwiecień 2004 r. Największy spadek dynamiki przywozu dotyczył wyrobów klasyfikowanych jako maszyny i urządzenia, produkty chemiczne i tworzywa sztuczne, wyroby metalurgiczne oraz artykuły rolne.

Po przystapieniu do Unii Europejskiej główną rolę we wzroście wartości importu odegrały fizyczne rozmiary dostaw z Rosji. W dużej jednak mierze związane to było ze wzrostem cen surowców energetycznych na światowych rynkach. Wartość importu paliw mineralnych z Rosji zwiększyła się w tym okresie o 1/3, podczas gdy na początku roku uległa ona nawet obniżeniu. Natomiast wartość importu pozostałych towarów z Rosji wzrosła w okresie maj - grudzień 2004 r. zaledwie o $18 \%$. Dla porównania można byłoby podać, że w pierwszych czterech miesiącach wzrost ten był o ponad $80 \%$. Przyczynił się do tego w dużym stopniu wzrost zakupów w tym kraju aluminium i wyrobów z aluminium (wzrost 2,5-krotny) i nawozów (wzrost blisko 3-krotny). W okresie maj - grudzień 2004 r. spadła również dynamika przywozu z większości pozostałych krajów trzecich. Wśród głównych dostaw- 
ców odwrotną tendencję zanotowano w przywozie z Korei oraz w nieco mniejszym stopniu z USA.

W przypadku eksportu w porównaniu z 2003 r. w pierwszych czterech miesiącach 2004 r. nastapiło przyspieszenie tempa jego wzrostu również do krajów trzecich (o ponad 45\%). Największy wpływ na wzrost sprzedaży do tych państw miały środki transportu, maszyny i urządzenia oraz wyroby metalurgiczne. Należy przy tym podkreślić, że są to grupy towarowe, które dominowały także w eksporcie do krajów trzecich (łącznie obejmowały one prawie 50\% sprzedaży do tej grupy krajów). Szczególnie wysoka była dynamika sprzedaży środków transportu (ponad $87 \%$ ) i wyrobów metalurgicznych (ponad $80 \%$ ). W obu przypadkach wzrost eksportu był przeszło 2-krotnie wyższy niż średnio w pozostałych grupach towarowych. Natomiast sprzedaż towarów klasyfikowanych w pozostałych grupach rosła w okresie styczeń - kwiecień 2004 r. wyraźnie wolniej niż średnio ogółem. Przy tym, najniższe tempo wzrostu wystapiło w grupach materiałów i wyrobów włókienniczych oraz artykułów rolnych. W grupie produktów rolnych dynamika eksportu była jednak bardzo zróżnicowana. $\mathrm{O}$ ile w przypadku produktów pochodzenia zwierzęcego i przetworów spożywczych nastąpił wzrost eksportu, o tyle w przypadku produktów pochodzenia roślinnego odnotowano znaczący (blisko 20\%) spadek sprzedaży.

Największe znaczenie dla wzrostu polskiego eksportu do krajów spoza UE na początku 2004 roku miało zdecydowane zwiększenie sprzedaży do Norwegii. Natomiast w okresie maj - grudzień 2004 r. nastapił już spadek wartości eksportu do tego kraju. Prawdopodobnie początkowo wynikało to ze znacznego eksportu statków do tego kraju. Powyższą tezę trudno jest jednak zweryfikować w odniesieniu do późniejszego okresu ze względu na brak danych. Niemniej jednak w ciagu pierwszych czterech miesięcy sprzedaż do tego kraju zwiększyła się przeszło 2,5-krotnie. Wyjątkowo szybki wzrost eksportu w tym okresie nastąił również do Turcji. Jak już zaznaczono, kraje trzecie były jedyną spośród wyodrębnionych tu grup krajów, w której dynamika eksportu w okresie maj - grudzień 2004 r. okazała się wyższa niż w okresie poprzedzającym członkostwo Polski w UE. Za krótki jest to jednak okres włączony do wstępnych badań, żeby można było zbyt daleko idące uogólnienia stosować na podstawie tych wyników. 
Wykres 2. Struktura geograficzna polskiego eksportu w 2004 r.
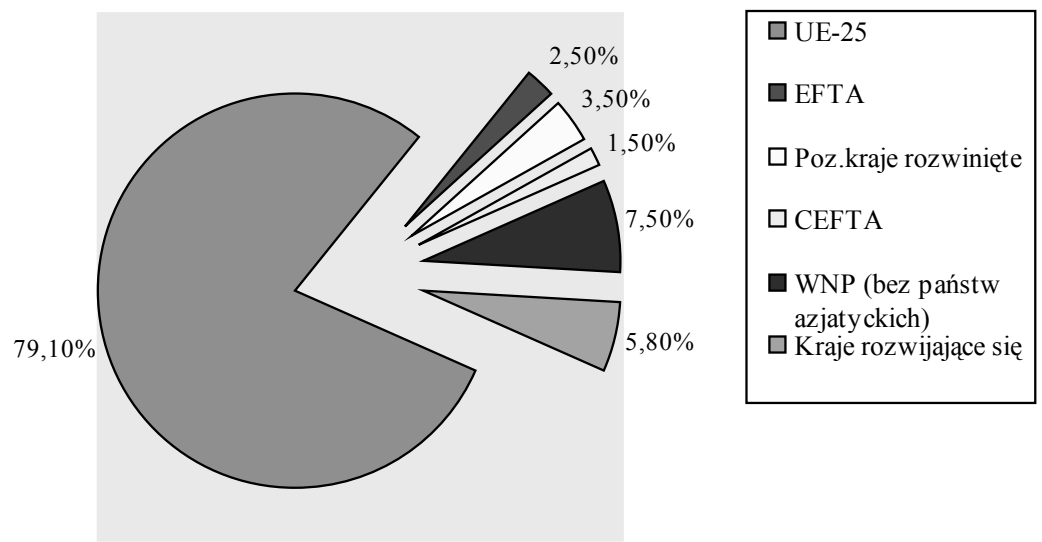

Źródlo: opracowanie własne na podstawie; Ocena sytuacji w handlu zagranicznym Polski w 2004 roku..., op. cit., s. 10.

Największą rolę w przyspieszeniu tempa wzrostu eksportu do krajów trzecich w okresie maj - grudzień 2004 r. miały maszyny i urządzenia. Była to bowiem najważniejsza obok środków transportu pozycja w eksporcie do krajów trzecich. Jednocześnie należy także podkreślić, że były to te wyroby, których tempo wzrostu eksportu do UE (łącznie dotychczasowych i nowych krajów członkowskich) obniżyło się w okresie maj - grudzień 2004 r. Szybciej niż w ciagu pierwszych czterech miesięcy 2004 r. rósł także eksport wyrobów metalurgicznych (o 86,5\%) oraz produktów chemicznych (79\%) i tworzyw sztucznych (57\%). Jednak najwyższym wzrostem sprzedaży do krajów trzecich w tym okresie charakteryzowały się produkty mineralne (143\%), przede wszystkim węgiel. Chociaż środki transportu utrzymały znaczącą rolę we wzroście eksportu także w okresie maj - grudzień 2004 r., to jednak tempo wzrostu ich eksportu obniżyło się o przeszło połowę w porównaniu z pierwszymi czterema miesiącami 2004 r. Znacznie mniejszą rolę we wzroście eksportu w okresie maj - grudzień 2004 r., w porównaniu z krajami UE, odegrały artykuły rolne (wzrost wywozu o niecałe 19\%). Wynikało to z bezwzględnego spadku sprzedaży produktów pochodzenia zwierzęcego - najważniejszej poprzednio grupy w eksporcie rolnym do krajów trzecich. Zasadniczym powodem takiej sytuacji było przede wszystkim wprowadzenie przez stronę rosyjską czasowego zakazu przywozu mięsa z krajów Unii, w tym także z Polski. Dalsze przyspieszenie tempa wzrostu polskiego eksportu ogółem od maja do grudnia 2004 r. nastapiło przede wszystkim w wyniku ponad 2-krotnego wzrostu eksportu do Rosji, która wówczas była już najważniejszym partnerem handlowym Polski spośród krajów trzecich. ${ }^{3}$ 
Tym samym wartość polskiego eksportu do Rosji po raz pierwszy przekroczyła poziom z roku 1997, a więc sprzed kryzysu rosyjskiego. Z kolei udział Rosji w polskim eksporcie do krajów trzecich wzrósł o 5,5 pkt proc. (do blisko 20\%). Warto dodać, że w styczniu 2005 r., w porównaniu ze styczniem 2004 r., wywóz do tego kraju wzrósł więcej niż dwukrotnie (o 125\%). Przyczyniło się do tego głównie zwiększenie eksportu w grupie obejmującej maszyny i urządzenia. Wzrost znaczenia w eksporcie do Rosji towarów o wyższym stopniu przetworzenia wskazuje na to, że głównym czynnikiem ekspansji na rynek rosyjski były już przedsiębiorstwa z udziałem kapitału zagranicznego. Warto zwrócić również uwagę na szybki wzrost eksportu do Turcji i Chin. Trudno jest jednak tutaj znaleźć bezpośredni związek z faktem przystąpienia Polski do UE.

W 2004 r. odnotowano pogłębianie się deficytu obrotów handlowych z krajami trzecimi. Przyczyną tego było przede wszystkim zwiększenie się ujemnego salda $\mathrm{w}$ handlu produktami mineralnymi ( $\mathrm{w}$ tej grupie deficyt w całym 2004 r. przekroczył 7 mld dol.). W okresie maj - grudzień 2004 r. nierównowaga między importem a eksportem powiększyła się również w handlu środkami transportu, materiałami i wyrobami włókienniczymi oraz maszynami i urządzeniami. Należy przy tym podkreślić, że ta ostatnia grupa, obok paliw mineralnych, generuje największą część deficytu w polskim obrocie towarowym z krajami trzecimi. Jednocześnie zmniejszyło się ujemne saldo w handlu produktami chemicznymi i powiększyło się dodatnie saldo w handlu wyrobami metalurgicznymi.

Głęboki deficyt w handlu z krajami trzecimi wynikał wówczas przede wszystkim z dużej nierównowagi między wartością importu a eksportu, jaka charakteryzuje obroty z Rosją i Chinami. Ujemne saldo w wymianie z Rosją zmniejszyło się jednak w 2004 r. o $140 \mathrm{mln}$ dol. (z czego o $130 \mathrm{mln}$ dol. w okresie maj - grudzień 2004 r.). W przypadku Chin deficyt pogłębił się. Ujemne saldo zwiększyło się także w wymianie z pozostałymi najważniejszymi azjatyckimi partnerami handlowymi Polski (Japonią, Koreą Południową i Tajwanem). Natomiast najwyższe dodatnie saldo w handlu z krajami trzecimi Polska osiagała w wymianie z innymi krajami Europy Środkowej i Wschodniej (Ukrainą, Rumunią i Chorwacją). W większości przypadków skala nadwyżki eksportu nad importem była większa jednak w okresie maj - grudzień $2004 \mathrm{r}$.

W 2005 roku, kiedy Unię Europejską stanowiło już 25 państw, ze zrozumiałych względów znacznie zwiększyły się jej obroty handlowe w wyrażeniu bezwzględnym. Ale jednocześnie eksport krajów UE - 25 wzrósł o 10\%, tj. o 100,1 mld euro, a import o $14 \%$, tj. o 142,7 mld euro. Wzrost eksportu nastapił we wszystkich ważniejszych grupach towarowych. Podstawową grupą towarową w handlu zagranicznym państw UE - 25 stanowią wyroby przemysłowe. Ich udział stanowił $85,9 \%$ całego eksportu UE. W ujęciu wartościowym wzrost eksportu w tej grupie towarowej wyniósł 73,3 mld euro. W handlu wyrobami przemysłowi UE - 25 odnotowała tak- 
Przepływ towarów przez polsko-rosyjską granicę...

że największe dodatnie saldo handlowe w kwocie 148,2 mld euro. Tradycyjnie już największy deficyt występuje w handlu surowcami. W 2005 roku, w związku z dużymi wzrostami cen surowców na światowych rynkach, w tym głównie ropy naftowej, zwiększył się on o kwotę 73,6 mld euro w tej grupie towarowej.

Tabela 2. Obroty handlowe Polski w latach 2004-2005 wg ugrupowań i krajów (w mln euro)

\begin{tabular}{|c|c|c|c|c|c|c|c|c|}
\hline \multirow{2}{*}{} & \multicolumn{3}{|c|}{$2004 \mathrm{r}}$. & \multicolumn{3}{c|}{$2005 \mathrm{r}}$. & \multicolumn{3}{c|}{ Dynamika } \\
\cline { 2 - 9 } & eksport & import & saldo & eksport & import & saldo & eksport. & importu \\
\hline $\begin{array}{c}\text { Polska } \\
\text { w tym: }\end{array}$ & 59.698 & 71354 & -11.656 & 71394 & 80.644 & -9250 & 119,6 & 113,0 \\
\hline $\begin{array}{c}\text { UE 25 } \\
\text { w tym: }\end{array}$ & 47.232 & 48.669 & -1.437 & 55.149 & 52.853 & 2.296 & 116,8 & 108,6 \\
\hline Niemcy & 17.909 & 17.397 & 512 & 20.118 & 19885 & 234 & 112,3 & 114,3 \\
\hline Francja & 3.603 & 4.795 & -1.192 & 4.414 & 4.844 & -430 & 122,5 & 101,0 \\
\hline Włochy & 3.647 & 5.619 & -1.972 & 4.357 & 5.668 & -1.311 & 119,5 & 100,9 \\
\hline $\begin{array}{c}\text { WIk. Bry- } \\
\text { tania }\end{array}$ & 2.368 & 3.229 & 861 & 4.018 & 2.478 & 1.539 & 124,4 & 104,7 \\
\hline $\begin{array}{c}\text { WNP } \\
\text { w tym: }\end{array}$ & 4.686 & 7.117 & -2.431 & 6.204 & 9.458 & -3.255 & 132,4 & 132,9 \\
\hline Rosja & 2.299 & 5.166 & -2.866 & 3.160 & 7.211 & -4.051 & 137,4 & 139,6 \\
\hline USA & 1.437 & 1.713 & -276 & 1.468 & 1.923 & -455 & 102,2 & 112,3 \\
\hline Chiny & 449 & 3.287 & -2.838 & 473 & 4.389 & -3.916 & 105,3 & 133,5 \\
\hline Japonia & 138 & 1.386 & -1.247 & 145 & 1.556 & -1.411 & 104,6 & 112,3 \\
\hline \hline
\end{tabular}

Źródto: Koniunktura gospodarcza w państwach Unii Europejskiej w 2005 roku, Ministerstwo Gospodarki, Warszawa 2006, s. 30.

Do najważniejszych partnerów handlowych Unii Europejskiej należały wówczas Stany Zjednoczone. Eksport do tego kraju stanowił 23,4\% całego eksportu UE25 , a dodatnie saldo handlowe zamknęło się kwotą 88,1 mld euro i było ono wyższe od osiagniętego $\mathrm{w}$ analogicznym okresie roku ubiegłego o 11,8 mld euro. $Z$ każdym kolejnym rokiem rosły też obroty handlowe z Chinami, przy czym zdecydowanie szybciej wzrasta import niż eksport. Unia Europejska odnotowała wtedy z Chinami największy deficyt handlowy. W 2005 roku wyniósł on 106,2 mld euro. Z każdym kolejnym rokiem on zwiększał się. Dla porównania 2003 roku wynosił euro 64,2 mld euro, a w 2004 roku zamknął się kwotą 79,3 mld euro. ${ }^{4}$ 
Trzecim, odgrywającym coraz większą rolę, partnerem handlowym UE-25 (a więc także już z Polską) jest Rosja. ${ }^{5} \mathrm{Z}$ każdym kolejnym rokiem wzrastały jej obroty handlowe z tym krajem. Szczególnie szybko wzrastał jednak import, co powoduje, iż systematycznie powiększa się deficyt handlowy państw UE-25 w handlu z tym krajem. W 1999 roku deficyt handlowy UE-15 (tzw. „starej piętnastki”) w handlu z Rosją wynosił 17,6 mld, a w 2005 roku (powiększonej o nowe 10 krajów) już 50,3 mld euro.

Przechodząc już do podsumowania tej części rozważań należy wyraźnie podkreślić, że w przypadku Polski, głównym partnerem handlowym przed i po akcesji były kraje UE. Inaczej kształtują się obroty handlowe Polski z partnerem na wschodzie, tj. z Rosją. Szybko rośnie eksport, ale jednocześnie import rośnie jeszcze szybciej. W 2005 roku eksport do Rosji wzrósł o 37,4\% i zamknął się kwotą 3,2 mld euro, a import o 39,9\% i wyniósł 7,2 mld euro. Ujemne saldo obrotów wzrosło tym samym do kwoty 4,1 mld euro z 2,9 mld euro w 2004 roku. Szczególnego podkreślenia wymaga fakt, że z żadnym innym krajem nie występuje tak duży deficyt w obrotach handlowych. Ten wzrost ujemnego salda wynikał głównie ze wzrostu wartości importu produktów mineralnych (sekcja V) o kwotę o 1,9 mld euro ${ }^{6}$. Niestety ta niekorzystna tendencja nie rokuje najmniejszych szans na odwrócenie w najbliższej przyszłości.

\section{Polsko-rosyjskie obroty towarowe w latach $2002-2005^{7}$}

Do momentu zintegrowania się Polski z UE, a zwłaszcza jeszcze w początkowych fazach transformacji, jak to dość szczegółowo przedstawiono już wcześniej, tj. w paragrafie 2., reorientacja polskiego handlu ze Wschodu na Zachód dokonywała się w relatywnie szybkim tempie. Polegało to głównie na skokowym wzroście udziału krajów rozwiniętych, w tym zwłaszcza UE. Dokonywało się to oczywiście kosztem krajów Europy Środkowej i Wschodniej. W tym okresie występowało również szybkie tempo spadku obrotów wymiany towarowej z Rosją. Niemniej jednak lata 1993-1997 charakteryzowały się jeszcze dynamicznym wzrostem polskiego eksportu na rynek rosyjski. W 1997 r. osiagnął on poziom 2155 mln dol.. Rok 1998, do miesiąca sierpnia włącznie, był jeszcze kontynuacją tego trendu. Jednakże, w wyniku załamania finansowego w Rosji w sierpniu

W latach 2003-2004 Komisja Europejska zaproponowała nowa politykę zagraniczną UE - „europejską politykę sąsiedztwa" (ENP - Europan Neighbourhood Policy), w związu z czym na szczycie w Sankt Petersburgu w maju 2003 roku zdecydowano, że stosunki UE - Rosja przyjmą postać tzw. „strategicznego partnerstwa”, por. A. Maksimczuk, A. Ejsmont, Unormowania Schengen a Europejska Polityka Sąsiedztwa (na przykładzie polskiej granicy wschodniej), (w:) M. Adamowicz, A. Siedlecka, (red.), Ruch graniczny w kontekście poszerzenia Unii Europejskiej... op. cit., s. 123 i dalsze.

$6 \quad$ Koniunktura gospodarcza w państwach Unii..., op. cit., s. 30-31.

7 Do bardziej szczegółowej analizy tych zagadnień wykorzystano także (jak podawano w przypisie nr 2) niektóre informacje opracowane przez Wydział Ekonomiczno-Handlowy Ambasady RP w Moskwie. 
1998 roku, eksport ten uległ drastycznemu spadkowi. Osiagnął w roku następnym poziom zaledwie $710 \mathrm{mln}$ dol., tj. ok. $31 \%$ jego wartości sprzed dwóch lat. Od roku 2000 stopniowo następowała już odbudowa pozycji polskich eksporterów na rynku rosyjskim. W roku 2003 eksport polskich towarów na rynek rosyjski wynosił już 1512,3 mln dol. W rzeczywistości oznaczało to, że nieznacznie przekroczył on poziom $70 \%$ wartości z roku $1997^{8}$. Wydawało się wówczas, że osiagnięcie poziomu polskiego eksportu do Rosji z roku 1997 będzie możliwe dopiero co najwyżej na koniec 2005 r. Jednakże już w roku 2004, mimo wielu obaw związanych z faktem wejścia Polski do UE, obroty wzajemne, w tym w szczególności polski eksport, rozwijały się wyjątkowo dynamicznie. Na koniec 2004 roku eksport, odnotowując niespotykaną dotychczas dynamikę, wzrósł o $88,8 \%$. Tym samym osiagnął rekordowy poziom 2854,6 mln dol. Był więc znacznie większy niż w najlepszym dotychczas 1997 roku. Import, wzrastając o 23,0\%, osiagnął również rekordowy poziom $6415,2 \mathrm{mln}$ dol. Oznacza to, że obroty osiagnęły nie notowany dotychczas poziom prawie 9,3 mld dol' .

Podobnie kształtowała się skala wymiany handlowej w 2005 r. Polska była tym samym już ósmym co do wielkości odbiorcą rosyjskich towarów - z udziałem w rosyjskim eksporcie w wysokości 3,72\%. Jednakże zarówno miejsce, jak też udział nie uległy większym zmianom w trzyletnim (2003-2005) przedziale czasowym obejmującym po jednym pełnym roku kalendarzowym przed 1 maja 2004 i po zintegrowaniu się Polski z UE. Według rosyjskiej statystyki celnej wartość rosyjskiego eksportu do Polski w roku 2005 przekroczyła 8,6 mld dol, wzrastając o 53,7\% w stosunku do roku 2004 (w 2004 r. wartość ta wyniosła 5,6 mld dol., w 2003 r. 4,4 mld dol). Jednakże blisko $90 \%$ rosyjskich dostaw handlowych do Polski stanowiły produkty mineralne, w tym ropa naftowa oraz gaz ziemny $86,0 \%{ }^{10}$.

W towarowej strukturze rosyjskiego importu z Polski największy udział miały maszyny, urządzenia i środki transportu 43,5\% (w 2004 r. 41\%), artykuły rolnospożywcze $17,7 \%(18,1 \%)$, wyroby przemysłu chemicznego $16,5 \%$ (15,9\%), metale i wyroby metalowe $7,7 \%(7,8 \%)$. Z tego $82,6 \%$ wartości importu przypadało na państwa trzecie (w 2004 r. 79,6\%). Już wówczas był mocno dostrzegalny spadek udziału importu krajów WNP - z 20,4\% w 2004 r. do 17,4\% w roku 2005. Polska, z blisko z 3\% udziałem, była wówczas jeszcze w rankingu dwunastym (12) partnerem handlowym Rosji.

8 Federacja Rosyjska. Przewodnik dla przedsiębiorców, wydanie drugie rozszerzone, BPI i TONZ ds. Rozwoju Przemysłowego, Warszawa 2004 (z suplementem - kwiecień 2005), s. 306 oraz Wywóz i wwóz towarów przez granicę Rosji przez osoby fizyczne, „Rynek Wschodni - Partnerzy” Warszawa 2004, nr 8.

9 J. Rudkowski, Obroty towarowe Polski z Rosją w 2004 r., „Przegląd Gospodarczo-Rynkowy, Biuletyn ekonomiczny" 2005, nr 1; WE-H Ambasady RP w Moskwie, Moskwa 2005, s.19.

10 Por. A. Maksimczuk, L. Sidorowicz, Polska granica wschodnia w warunkach transformacji... op. cit., s.139-140. 
Aleksander Maksimczuk

Tabela 2. Polsko-rosyjskie obroty handlowe w latach 2002-2005 (w mln dol.)

\begin{tabular}{|c|c|c|c|c|c|c|c|}
\hline & 2002 r. & 2003 r. & $\begin{array}{c}\text { dynamika } \\
03) 02\end{array}$ & 2004 r. & $\begin{array}{c}\text { dynamika } \\
04) 03\end{array}$ & 2005 r. & $\begin{array}{c}\text { dynamika } \\
05) 04\end{array}$ \\
\hline Eksport do Rosji & 1331,8 & 1512,3 & 113,6 & 2842,7 & 188,0 & 3960,5 & 139,3 \\
\hline Import z Rosji & 4407,4 & 5214,7 & 118,3 & 6390,6 & 123,0 & 8985,5 & 140,6 \\
\hline Obroty & 5739,2 & 6727,0 & 117,2 & 9233,3 & 137,3 & 12946,0 & 140,2 \\
\hline Saldo & $-3075,6$ & $-3702,4$ & $\mathrm{x}$ & $-3547,9$ & $\mathrm{x}$ & $-5025,0$ & $\mathrm{x}$ \\
\hline
\end{tabular}

Źródło: opracowanie własne na podstawie danych GUS.

W analizie polskiego eksportu na rynek rosyjski należy odnotować, że w 2005 roku generalnie utrzymała się wysoka konkurencyjność polskiego eksportu (określana dynamiką i udziałem polskich towarów w dostawach do Rosji), przy dalszym zachowaniu zróżnicowania konkurencyjności poszczególnych pozycji towarowych. Według rosyjskiej statystyki celnej, w 2005 roku polski eksport do Rosji w branży artykułów rolno-spożywczych wyniósł 588,8 $\mathrm{mln}$ dol. Oznaczało to wzrost o $12,8 \%$ w porównaniu z 2004 rokiem. Artykuły rolno-spożywcze stanowiły $21,5 \%$ polskiego eksportu na ten rynek. Pogorszyła się jednak konkurencyjność tej branży na ryn$\mathrm{ku}$. Stało się to między innymi z uwagi na szybsze tempo wzrostu rosyjskiego importu ogółem, które w 2005 roku wynosiło $27 \%$. $^{11}$

W eksporcie artykułów rolno - spożywczych mieliśmy do czynienia z dwiema różnowektorowymi tendencjami. $\mathrm{Z}$ jednej strony dynamicznie rozwijał się dotychczas eksport towarów pochodzenia roślinnego (w 2005 roku wzrost o 24,4\% wobec wzrostu globalnego importu Rosji o 19,7\%) oraz gotowych wyrobów spożywczych $\mathrm{z}$ tych surowców. Pozytywne tendencje dotyczyły warzyw i owoców świeżych (szczególnie jabłek - ok. 11\% udział w imporcie rosyjskim, ale też warzyw kapustnych - ponad 2,4-krotny wzrost polskiego eksportu oraz zwiększenie udziału polskich dostaw w globalnym imporcie Rosji z 28,6\% w 2004 roku do 37\% w 2005 roku i innych), a także ich przetworów (mrożonych i niemrożonych). Wzrastała też rola dostaw z Polski takich towarów, jak kwiaty, sadzonki, krzewy (wzrost eksportu np. w pozycji pozostałe rośliny żywe o $18 \%$ oraz udziału w rosyjskim imporcie z $19 \%$ do $22 \%$ ).

W kwestii innych gotowych artykułów spożywczych i napojów należałoby odnotować fakt, że w 2005 r. powróciły na rosyjski rynek wody mineralne z Polski $(2,8-$ krotny wzrost eksportu oraz ich udziału w rosyjskim imporcie z 13,7\% do ponad $25 \%$ ). Zwiększyły się również dostawy przetworów zbożowych (wzrost eksportu o $57 \%$ oraz udziału w rosyjskim imporcie z $51 \%$ do $59 \%$ ), przypraw (stały ok. $15 \%$ 
udział polskich dostaw w rosyjskim imporcie w pozycji sosy i przetwory), wyrobów piekarniczych (wzrost eksportu o 46\% oraz udziału w rosyjskim imporcie z 14,5\% do ponad 16\%), cukierniczych (wzrost eksportu o 23,3\%, stabilny ok. 13\% udział $\mathrm{w}$ rosyjskim imporcie).

Na ogół korzystnie kształtowała się również sytuacja w polskim eksporcie do Rosji m.in. takich towarów, jak cukier, przetworzony tytoń oraz koncentraty kawy i herbaty. Niestety, od 14 listopada 2005 r. Rosja wprowadziła czasowe ograniczenia na przywóz z Polski towarów pochodzenia roślinnego podlegających kontroli fitosanitarnej. Ograniczeniami objęto więc szeroki krąg towarów: cebulki, kwiaty, części roślin, warzywa świeże, ochłodzone i suszone, owoce świeże i suszone, przyprawy, kawę, zboża, mąkę, słód, nasiona, materiały roślinne dla wypychania i wyściełania, korę drzewna, pasze kombinowane, grunt, torf, kultury mikroorganizmów, skóry surowe, drewno opałowe $\mathrm{i}$ inne nieobrobione wyroby $\mathrm{z}$ drewna, opakowania $\mathrm{z}$ drewna, palety drewniane, papier i karton, opakowania z papieru i tektury, włókna bawełniane i odpady, surowiec lniany i inne. Tym samym dynamika wzrostu eksportu towarów podlegających kontroli fitosanitarnej uległa wyraźnemu zahamowaniu pod koniec 2005 roku.

Tracą swoje pozycje na rynku rosyjskim także polskie towary pochodzenia zwierzęcego oraz gotowe artykuły spożywcze pochodzenia zwierzęcego. Dotyczyło to praktycznie wszystkich towarów: mięsa wieprzowego, serów i twarogów, jogurtów i kefirów oraz innych produktów mleczarskich, mięsa drobiowego, kiełbas, konserw rybnych, co podyktowane jest m.in. problemami związanymi z wprowadzeniem przez Rosję w 2004 roku wymogu posiadania tzw. jednolitych świadectw weterynaryjnych i w konsekwencji ograniczeniem dostępu do rynku rosyjskiego dla wielu dotychczasowych i nowych polskich eksporterów. Sytuacja ta polskim producentom stała się szczególnie dotkliwa, gdyż w sposób nieunikniony prowadziła do utraty określonych segmentów rynku rosyjskiego ${ }^{12}$.

Podobne negatywne tendencje dotyczyły także niektórych innych produktów: mlecznych, mięsa drobiowego, konserw rybnych, ale jednocześnie mamy do czynienia ze wzrostem łącznego importu rosyjskiego w większości wymienionych pozycji towarowych. Dodatkowym problemem stało się wprowadzenie przez stronę rosyjską od 10 listopada 2005 roku ograniczenia wwozu z Polski do Rosji niektórych towarów mięsnych. Zakaz obejmował: wołowinę i półprodukty wołowe, wie-

12 Wśród przykładów, gdzie odnotowujemy zasadnicze spadki dostaw, można wymienić m.in.: mięso wieprzowe (w 2004 roku dostawy z Polski plasowały się na czwartym miejscu z 5\% udziałem w rosyjskim imporcie - po bezwzględnym liderze Brazylii oraz Niemczech i Chinach, natomiast w 2005 roku nasz udział w imporcie FR spadł o ponad 3 punkty procentowe oraz poza Brazylią i Niemcami wyprzedzili nas także eksporterzy z USA, Danii i Holandii. Tendencje te zachodzą w warunkach wysokiej jakości i niskich cen polskiej oferty), sery i twarogi (w 2004 r. ponad 4\% udział dostaw z Polski w rosyjskim imporcie plasował nas na piątym miejscu - po Ukrainie, Niemczech, Finlandii i Litwie, natomiast w 2005 r. nasz udział obniżył się o ponad 2 punkty procentowe i poza wyżej wymienionymi wyprzedzili nas również eksporterzy z Holandii, Francji, a nawet Argentyny). 
przowinę i półprodukty wieprzowe, mięso drobiu i farsz z mięsa drobiowego, a także surowe półprodukty mięsne ${ }^{13}$.

Wystapienie tych niekorzystnych zjawisk zaistniało w momencie, gdy prognozowany był wzrost chłonności i zapotrzebowania rynku rosyjskiego na artykuły rolno-spożywcze. W związku z tym polscy przedsiębiorcy zaczęli tworzyć konkurencyjną ofertę eksportową, która powinna mieć wszelkie szanse realizacji w Rosji, w tym poprzez odbudowanie istniejących i tworzenie nowych trwałych powiązań handlowych. Coraz śmielej niektóre z firm zabrały się również za podejmowanie inwestycji w Rosji (m.in. w sferze produkcji napojów, przypraw, wyrobów cukierniczych). Docelowo miało to zwiększyć możliwości stabilnej polskiej obecności gospodarczej na rynku rosyjskim w branży rolno-spożywczej. Warunkiem praktycznej realizacji wymienionych możliwości wzrostu polskiego eksportu jest przede wszystkim likwidacja istniejących barier i ograniczeń w dostępie do rynku rosyjskiego, w tym uzgodnienie warunków, które w bliższej lub dalszej przyszłości powinny doprowadzić do przywrócenia w pełnym zakresie możliwości dostaw polskich wyrobów pochodzenia roślinnego i zwierzęcego na rynek rosyjski. Ponadto nieodzowne stawało się już wówczas wypracowanie efektywnych procedur kontroli maksymalnej ilości polskich zakładów w celu uzyskania rosyjskich certyfikatów warunkujących realizację eksportu do Rosji.

Relatywnie korzystnie kształtowała się sytuacja w polskim eksporcie do Rosji produktów przemysłu chemicznego, którego wartość w 2005 roku wynosiła 484,2 mln dol. O ile jednak w 2004 roku dynamika polskich dostaw (+49\%) wyprzedzała tempo wzrostu łącznego rosyjskiego importu (+24\%), to w 2005 roku mieliśmy do czynienia z odwrotną tendencją - polski eksport zwiększył się $20 \%$, podczas gdy globalny import Rosji wzrósł o 37\%. Ważną pozycją towarową w tej branży są preparaty farmaceutyczne. Stopniowo zaczęły one odzyskiwać poprzednio utraconą pozycję na rynku rosyjskim. Polski eksport tych produktów w 2005 r. zwiększył się o ponad $66 \%$, przy wzroście ich łącznego rosyjskiego importu o 52\%. Może to być potraktowane jako kolejna pozytywna tendencja obserwowana również w 2004 roku - wzrost już wtedy polskiego eksportu o 50\%, wobec wzrostu rosyjskiego importu ogółem o $26 \%$. W zakresie dostaw farmaceutyków w 2005 r. odnotowano najwyższy wartościowy przyrost polskiego eksportu: $+62 \mathrm{mln}$ dol w stosunku do 2004 roku. Polski eksport leków posiadał w analizowanym okresie stabilny ok. 4\% udział w rosyjskim imporcie. Byliśmy wówczas 8 dostawcą farmaceutyków do Rosji, ustępując bezwzględnym liderom - dostawcom z Niemiec i Francji, a także eksporterom z Indii, Węgier, Włoch, Szwajcarii, Słowenii ${ }^{14}$. 
W tym okresie zasadniczo wzrosła także pozycja polskich kosmetyków. W 2004 roku ich eksport wynosił $187 \mathrm{mln}$ dol. (wzrost o 49\%, wobec wzrostu rosyjskiego importu ogółem o 32\%). W 2005 roku nastapił nieznaczny spadek eksportu kosmetyków o 3,7\% (180,1 mln dol.), podczas gdy łączny import Rosji zwiększył się o $17,5 \%$. Pomimo to wciąż szereg towarów z tej grupy dostarczanych z Polski zachowało liczącą się pozycję na rynku rosyjskim. Dotyczyło to m.in. preparatów do upiększania, makijażu i pielęgnacji skóry, których udział przekracza 19\% w łącznym rosyjskim imporcie (głównie kosmetyki białej - kremów), preparatów do włosów (ok. 16\% udział w rosyjskim imporcie), wód toaletowych (ponad 15\% udział w rosyjskim imporcie), jednak ich udział w 2005 roku uległ generalnie obniżeniu. Należy mieć jednak nadal na uwadze to, że rosyjski rynek perfumeryjno-kosmetyczny należał już wówczas do szybko rozwijających się segmentów rynku konsumpcyjnego i to powinno mieć wpływ na zmiany tempa i struktury tych obrotów.

Wzrastało także zainteresowanie importem z Polski wyrobów z branży tworzyw sztucznych. W 2004 roku polski eksport tych towarów wynosił 159,3 mln dol. (wzrost o 39\% wobec wzrostu łącznego importu rosyjskiego o 33\%). Natomiast w 2005 roku polskie dostawy tych wyrobów wyniosły 238,3 mln dol. (wzrost o 50\% wobec wzrostu łącznego importu Rosji również o 50\%). Szczególnie dynamicznie wzrastały także dostawy z Polski takich towarów, jak: artykuły do transportu i pakowania towarów z tworzyw sztucznych (w 2005 roku 52,6 mln dol., wzrost dostaw o $62 \%$ oraz wzrost udziału w rosyjskim imporcie z 16\% 2004 roku do 17,1\% w 2005 roku), pozostałe płyty, arkusze, folie, taśmy z tworzyw sztucznych (w 2005 roku 34,4 mln dol., wzrost dostaw o 49\%, ok. 9\% udział w rosyjskim imporcie), włókna z tworzyw sztucznych $(25,1 \mathrm{mln}$ dol., 3,3-krotny wzrost dostaw, 12,5\% udział w rosyjskim imporcie), opony pneumatyczne (11,9 mln dol., wzrost dostaw o 44\%, ok. $2,5 \%$ udział w rosyjskim imporcie) i niektórych innych wyrobów ${ }^{15}$. Chłonność rosyjskiego rynku kreowana była w tym okresie głównie przez rynkowe czynniki popytowe. W związku z tym tempo wzrostu importu według ówczesnych szacunków mogło wynosić nawet ok. 25-30\% w skali rocznej. A to tym samym mogło tworzyć dogodne warunki dla wzrostu polskiego eksportu.

W analizowanym okresie (integrowanie się Polski z UE) nieco zmniejszał się udział polskich dostaw drewna i wyrobów z drewna. W 2004 roku polski eksport wynosił $53 \mathrm{mln}$ dol. (wzrost o 18\% wobec wzrostu rosyjskiego importu ogółem o 29\%). Natomiast w 2005 roku osiagnął on już poziom 60,2 $\mathrm{mln}$ dol. (wzrost o $13,6 \%$ wobec wzrostu rosyjskiego importu ogółem o 20,1\%). W konsekwencji udział polskich dostaw w łącznym imporcie rosyjskim obniżył się z 16,8\% w 2004 roku do 15,9\% w 2005 roku. Podstawowym produktem w polskim eksporcie z tej grupy towarów były płyty wiórowe. W 2005 roku wartość ich dostaw wynosiła 32,6 
mln dol. (wzrost eksportu o 24\%, ponad 32\% udział w rosyjskim imporcie). Eksport wyrobów z drewna już wówczas zaczął napotykać wzrastającą konkurencję produkcji w Rosji (uruchamiano m.in. w rejonie Wielkiego Nowgorodu duży zakład produkcyjny firmy Pfleiderer-Grajewo). Należy tu mocno podkreślić, że polityka Rosji, w tym realizowana przez jej administracje regionalne, zaczęła nastawiać się coraz bardziej na uruchamianie maksymalnie głębokiego przetwórstwa drewna bezpośrednio na swoim terytorium. Polityka taka została ukierunkowana na przeciwdziałanie wywozowi drewna surowego z tego kraju. Jednocześnie jednak stwarzało to często także skuteczną konkurencję dla importu wyrobów z drewna. Czynniki te ograniczały możliwości wzrostu polskiego eksportu do Rosji nie tylko zresztą w tej branży.

Stosunkowo mocną pozycję na rynku rosyjskim posiadały polskie dostawy w branży: ścier drzewny lub z innego włóknistego materiału celulozowego; papier lub tektura z odzysku oraz wyroby z nich wytwarzane (sekcja X). Eksport, realizowany przede wszystkim w pozycji towarowej: papier i tektura, wyroby z masy papierniczej, papieru lub tektury, osiagną w 2004 roku poziom $237 \mathrm{mln}$ dol. (wzrost o 19\% wobec wzrostu importu ogółem o 26\%). Natomiast w 2005 roku ich eksport wyniósł już 272,9 mln dol. (wzrost o 15,1\% wobec wzrostu ich łącznego importu FR o 19,2\%). Do grup towarowych już wówczas stopniowo odbudowujących swoją pozycję na rynku rosyjskim należy zaliczyć także: materiały i wyroby włókiennicze. Osiagnęły one 2,6\% udział w rosyjskim imporcie tych wyrobów.

Dynamicznym wzrostem charakteryzował się również polski eksport ${ }^{16}$ :

- obuwia (poza obuwiem skórzanym, którego dostawy zmniejszyły się w 2005 roku o ok. 10\%). Według statystyki rosyjskiej, import obuwia z Polski zwiększył się o 78\% w 2004 r. i o 51\% w 2005 r. (wartość dostaw z RP 14,1 mln dol.),

- wyrobów z kamieni, gipsu, cementu - 160,6 mln dol. w 2005 roku (import z Polski stanowił ok. 11\% całego przywozu do Rosji), a także innych materiałów budowlanych,

- metali nieszlachetnych i wyrobów z metali nieszlachetnych. W 2004 r. nastapił wzrost tych dostaw z udziałem w rosyjskim imporcie w wysokości $2,5 \%$,

- maszyn, urządzeń, środków transportu, przyrządów.

W 2005 roku wartość polskiego eksportu w danej grupie wyniosła ponad 537 mln dol., co stanowiło już 19,5\% całości polskiego eksportu do Rosji. Poza wyżej 
wymienionymi grupami produktów i towarów znaczące pozycje stanowiły również takie towary, jak: kombajny zbożowe (wzrost dostaw o 29\% przy wzroście rosyjskiego importu ogółem o 33\%, stabilny ok. 3\% udział w rosyjskim imporcie), silniki spalinowe (wzrost dostaw o 56\% przy wzroście rosyjskiego importu o $62 \%$, wzrost udziału w rosyjskim imporcie z 5,9\% do 7,2\%), a także maszyny i urządzenia mechaniczne przeznaczone do wykonywania funkcji specjalnych, części i akcesoria samochodowe, maszyny budowlano-drogowe, przewody izolowane, pralki automatyczne, przyczepy rolnicze, transformatory elektryczne, urządzenia elektryczne do przełączania i zabezpieczania obwodów elektrycznych, akumulatory elektryczne.

Zwiększały się również dostawy mebli z Polski (tendencja wieloletnia). Należy przy tym szczególnie podkreślić, że dokonywało się to pomimo na ogół niekorzystnej dla polskich eksporterów konstrukcji importowej taryfy celnej Rosji (stosowane kombinowane stawki celne stanowią barierę dla dostaw tradycyjnych mebli drewnianych z Polski). W 2005 roku wartość polskiego eksportu mebli wynosiła 62,5 mln dol. Dostawy z Polski w 2005 roku wzrosły o 28,6\%, przy 23\% wzroście rosyjskiego importu ogółem. Dotyczyło to w szczególności mebli drewnianych do mieszkań (stabilny ponad 9\% udział w łącznym rosyjskim imporcie). Należy jednak nadmienić, że już wówczas rosnąca chłonność rynku rosyjskiego na meble zaczyna być zaspokajana w coraz większym stopniu poprzez produkcję krajową, jak również import z takich krajów, jak Białoruś czy Ukraina. Odnotować należy przy tym coraz to wyraźniejsze możliwości wzrostu polskiego eksportu w zakresie komponentów i akcesoriów do produkcji mebli.

Oprócz przedstawionej powyżej analizy odnoszącej się głównie do wybranych najważniejszych towarów, w ogólnym rachunku oceny polskich perspektyw eksportowych na rynek rosyjski uwzględnić należy także usługi budowlane. Ta część rynku rosyjskiego charakteryzowała się także w badanych latach dużym potencjałem rozwojowym, sięgającym 20-60\% dynamiką wzrostu i dotyczącym wszystkich segmentów tego rynku (budownictwa mieszkaniowego, hotelowo-biurowego, handlowo-rekreacyjnego oraz konserwatorsko-rekonstrukcyjnego). Sytuacja taka stwarzała tym samym dodatkowe możliwości dla polskich firm budowlanych, oferujących odpowiedni potencjał wykonawczy ${ }^{17}$.

Według danych rosyjskiej statystyki celnej, w 2005 roku największy wartościowo (w porównaniu z 2004 rokiem) przyrost eksportu do Rosji dotyczył: preparatów farmaceutycznych $(+62,0 \mathrm{mln}$ dol.), urządzeń do filtrowania lub oczyszczania cieczy lub gazów; wirówek, także suszarek wirnikowych $(+32,0 \mathrm{mln}$ dol. $)$, papieru, tektury, waty celulozowej i wstęg z włókien celulozowych, powlekanych, impregnowanych $(+20,4 \mathrm{mln}$ dol.), artykułów do transportu i pakowania towarów z two- 
rzyw sztucznych; korków, pokrywek, kapsli i pozostałych zamknięć z tworzyw sztucznych (+20,2 mln dol.), kitu szklarskiego, kitu ogrodniczego, kitów żywicznych, mas uszczelniających i pozostałych mastyksów; wypełniaczy malarskich, nieogniotrwałych preparatów powierzchniowych do fasad, ścian wewnętrznych, podłóg, sufitów itp. (+19,0 mln dol.), artykułów higienicznych - podpasek, pieluszek, chusteczek itp. $(+18,6 \mathrm{mln}$ dol.), włókien pojedynczych - powyżej $1 \mathrm{~mm}$, prętów, pałeczek i kształtowników profilowanych z tworzywa sztucznego $(+17,6 \mathrm{mln}$ dol.), elektrycznych podgrzewaczy do wody, grzałek nurnikowych, elektrycznych urządzeń do ogrzewania gleby i pomieszczeń, elektrotermicznych przyrządów fryzjerskich, suszarek do rąk, elektrycznych żelazek do prasowania, urządzeń elektrotermicznych w rodzaju stosowanych do użytku domowego, elektrycznych oporowych elementów grzejnych $(+14,0 \mathrm{mln}$ dol.), pozostałych płyt, arkuszy, folii, taśm i pasów z tworzyw sztucznych $(+11,3 \mathrm{mln}$ dol.), brzytew, maszynek do golenia i żyletek $(+10,9$ mln dol.), jabłek, gruszek $(+10,3 \mathrm{mln}$ dol.), pozostałych warzyw przetworzonych lub zakonserwowanych inaczej niż za pomocą octu lub kwasu octowego mrożonych (+10,2 mln dol.).

Największy wartościowo spadek polskiego eksportu do Rosji w 2005 roku objął: maszyny i urządzenia odlewnicze dla hutnictwa $(-42,0 \mathrm{mln}$ dol.), mięso wieprzowe (-15,7 mln dol.), statki rybackie (-11,4 mln dol.), drukowane książki, broszury, ulotki i podobne materiały drukowane $(-9,8 \mathrm{mln}$ dol.), pozostałe maszyny do przemieszczania, równania, niwelowania, zgarniania, kopania, ubijania, minerałów lub rud, urządzenia do wbijania lub wyciaggania pali; pługi odśnieżające lemieszowe i wirnikowe $(-8,1 \mathrm{mln}$ dol.), dżemy, galaretki owocowe, marmolady, przeciery i pasty owocowe $(-8,0 \mathrm{mln}$ dol.), artykuły mleczne $(-7,5 \mathrm{mln}$ dol.), morele, wiśnie, brzoskwinie, śliwki świeże (-6,7 $\mathrm{mln}$ dol.), elektrody węglowe, węgle do lamp, węgiel do baterii i inne wyroby z grafitu lub innego rodzaju węgla, w rodzaju stosowanych w elektrotechnice $(-6,4 \mathrm{mln}$ dol.), preparaty stosowane przed goleniem, do golenia lub po goleniu, dezodoranty osobiste, preparaty do kapieli, depilatory i pozostałe preparaty perfumeryjne, kosmetyczne i toaletowe $(-5,7 \mathrm{mln}$ dol.), organiczne środki powierzchniowo czynne, preparaty powierzchniowo czynne, preparaty do prania oraz preparaty czyszczące $(-5,5 \mathrm{mln}$ dol.), kartony, pudła, torby i pozostałe pojemniki opakowaniowe z papieru i tektury, segregatory, pudełka na listy itp. wyroby biurowe $(-5,2 \mathrm{mln}$ dol.).

Wśród polskich towarów dostarczanych do Rosji w 2005 roku (o wartości powyżej $5 \mathrm{mln}$ dol.) największy udział w rosyjskim imporcie posiadały: pozostałe warzywa przetworzone lub zakonserwowane inaczej niż za pomocą octu lub kwasu octowego mrożone $(71,5 \%)$, warzywa mrożone $(67,8 \%)$, trzoda chlewna żywa $(67,3 \%)$, owoce mrożone $(64,2 \%)$, szkło lane i walcowane $(60,0 \%)$, przetwory spożywcze otrzymywane przez spęcznienie lub prażenie zbóż lub produktów zbożowych (np. płatki kukurydziane), zboża (inne niż kukurydziane) w postaci ziar- 
na lub płatków (58,9\%), artykuły higieniczne - podpaski, pieluszki, chusteczki itp. $(39,3 \%)$, kapusta i warzywa kapustne $(37,0 \%)$, wyroby z gipsu lub z mieszanek na bazie gipsu $(32,6 \%)$, płyty wiórowe $(32,5 \%)$, wyroby $z$ asfaltu lub podobnego materiału (29,7\%), dżemy, galaretki owocowe, marmolady, przeciery i pasty owocowe $(29,7 \%)$, wody, w tym wody mineralne $(25,1 \%)^{18}$.

Z konieczności już reasumując te rozważania, należy stwierdzić, że jednak pomimo pewnych trudności w eksporcie do Rosji znacznej ilości produktów pochodzenia rolniczego, współpraca handlowa między Polską a Rosją w analizowanym okresie rozwijała się na ogół dość dynamicznie. W 2005 roku (podobnie jak w poprzednich latach) w wielu branżach i sektorach kontynuowany był wzrost konkurencyjności polskich towarów. Dotyczyło to m.in. niektórych artykułów rolno-spożywczych, leków, chemii gospodarczej, mebli, niektórych wyrobów elektromaszynowych i towarów rynkowych. Co jest też niezwykle ważne (spostrzeżenie także odnotowane przez Wydział Ekonomiczno- Handlowy Ambasady RP w Moskwie), że już wówczas dawało się zauważać znaczne zainteresowanie lokalnego biznesu współpracą z Polską.

\section{Zakończenie}

Przechodząc do podsumowania powyższych rozważań można sformułować przynajmniej kilka następujących uogólnień, stwierdzeń, a może nawet wniosków wynikających z tutaj czynionych analiz:

1. Realizowana transformacja systemu gospodarczego i z niej dalej wynikające dążenie do zintegrowania się Polski z UE musiały wywoływać różne następstwa. Jednym z nich była systematycznie dokonująca się zmiana kierunku i struktury handlu zagranicznego. Zmiany struktury geograficznej polskiego handlu zagranicznego w latach 1990-2006 z kierunku wschodniego na zachodni należy ogólnie pozytywnie ocenić.

2. Wiele argumentów można przytoczyć na potwierdzanie tezy, że: „właśnie w znacznym stopniu za pośrednictwem handlu zagranicznego dokonywała się integracja rynkowa Polski z krajami UE”. I rzeczywiście to pokazują wyniki i wskaźniki z analizy obrotów polskiego handlu zagranicznego w tym okresie. Ale również można i trzeba byłoby postawić w związku z tym także inną tezę, że: „za pośrednictwem handlu zagranicznego także dokonywata dezintegracja i coraz bardziej uwidaczniajace się oddalanie sie Polski od rynkowych więzi z wieloma krajami Europy Wschodniej - w tym głównie z Rosja”. 
3. Rosnące znaczenie unijnych rynków daje z pewnością Polsce wiele $\mathrm{z}$ tego tytułu wynikających korzyści. Niemniej jednak znaczna utrata sąsiedzkich rynków wschodnich i potencjalne trudności ich zdobycia muszą być postrzegane jako niewykorzystana szansa rozwoju polskiego handlu zagranicznego - jako coś w rodzaju alternatywnej straty na innym odcinku współpracy, poprzednio nawet bardzo intensywnej i ważnej.

4. Istnieją różnego rodzaju utrudnienia rozwoju współpracy Polski z krajami Europy Wschodniej. Niestety, jednak dość często czynniki polityczne tę szansę zaprzepaszczają. Polskie firmy jednak nawet w takich warunkach stają się coraz bardziej skuteczne w zdobywaniu tych rynków.

5. Nie sposób byłoby przytoczyć argumenty, które mogłyby potwierdzać wcześniej wysuwane nawet dość często przypuszczenie, że integracja Polski z UE była siłą sprawczą obniżenia się dynamiki polsko-rosyjskich obrotów towarowych. Bowiem, jak pokazała tutaj przeprowadzona analiza, mimo pewnych trudności w eksporcie do Rosji niektórych polskich produktów (zwłaszcza pochodzenia rolniczego), współpraca handlowa między Polską i Rosją rozwijała się dynamicznie w momencie integrowania się Polski z UE i nie ma większych powodów, aby potem i obecnie mogło być inaczej.

6. W Rosji już w momencie poszerzania się UE na wschód występowało i wciąż dalej występuje rosnące zainteresowanie lokalnego biznesu współpracą z Polską. Spośród wielu czynników tworzących takie zainteresowanie ważną rolę odgrywa tu także fakt, że w strukturze podmiotowej polskiego eksportu do Rosji znaczący jest udział zlokalizowanej w Polsce produkcji koncernów światowych. Ważnym partnerem dla rosyjskich firm prowadzących działalność w sferze handlu zagranicznego są też polskie małe i średnie przedsiębiorstwa powiązane ścisłymi więzami z tymi koncernami światowymi. 
Przepływ towarów przez polsko-rosyjską granicę...

ПЕРЕМЕЩЕНИЕ ТОВАРОВ ЧЕРЕЗ ПОЛЬСКО-РОССИЙСКУЮ ГРАНИЦУ. ПОЛЬСКО-РОССИЙСКАЯ ВНЕШНЯЯ ТОРГОВЛЯ В ПЕРИОД ИНТЕГРАЦИИ ПОЛЬШИ С ЕС. ИЗБРАННЫЕ ЭКОНОМИЧЕСКИЕ АСПЕКТЫ

С трансформацией, интеграцией и глобализацией неизбежно меняются функции государственных границ. Интеграция Польши с ЕС автоматически изменила степень проницаемости восточной польской границы. Как это повлияло на польско-российский торговый обмен? Это центральный вопрос в настоящей статье. Результаты исследований показали, что после некоторого замедления темпа торгового оборота в период интеграции Польши с ЕС, в дальнейшем этот оборот интенсифицировался и в настоящее время приближается к прежнему уровню. Отсюда вполне обоснованным является также поиск и анализ важнейших аспектов, создающих основы формирования дружественного режима границ. А последний в свою очередь являются одним из многих элементов добрососедских отношений Польши и Российской Федерации. 


\section{THE MOVEMENT OF GOODS ACROSS THE POLISH-RUSSIAN BORDER. POLISH-RUSSIAN FOREIGN TRADE AT THE TIME OF POLISH INTEGRATION WITH THE EU. SELECTED ECONOMIC ASPECTS}

Together with transformation, integration and globalization, inevitably, the functions of national frontiers change. Polish integration with the EU automatically changed the permeability of the Polish eastern border. How did this affect PolishRussian trade? This question was the focus of the present study. The results of this on-going analysis have shown that after a slight slowdown in the rate of change of sales during the period of Polish integration with the EU, growth and a return to former levels followed. Thus, the next reasonable step appeared to be to examine the most important and easily available conditions for economic cooperation, which form the basis for the development of friendly borders. These in turn are just one of many important elements for good neighbourly relations between the societies of Poland and the Russian Federation.

Key words:

Transformation, integration, globalization, sales, Russia, Poland, borders 